\title{
Impact of Corruption on Economic Growth: Evidence from Asian Countries
}

\author{
Dr. Muhammad Zubair Mumtaz ${ }^{*}$ \& \\ Dr. Zachary A. Smith ${ }^{* *}$
}

\begin{abstract}
Previous literature argues that corruption hampers economic performance. Moreover, there is limited literature available on the interaction between corruption, government spending, and its effect on the overall economic taxonomy in Asia. This study employs the use of various classifications of government expenses and then analyses their impact on economic performance using different measures of corruption. The findings provide evidence that corruption has an inverse effect on military spending but concurrently it has an indirect and negative impact on economic activity within a country. This study also contrasts the findings of corruption and economic growth in Asian and African countries reporting that a higher level of corruption is deterring economic growth for Asian economies. The policy implications suggest that the association between corruption and economic growth is worsening in countries that utilise excessive government expenditures. Hence it is imperative that states monitor their government spending more closely to eliminate the corrupt practices.
\end{abstract}

Keywords: Corruption, Military Spending, Development Economics, Asian and African Countries

*The author is Associate Professor at the School of Social Sciences \& Humanities, National University of Sciences \& Technology (NUST), Islamabad, Pakistan. He can be contacted at: zubair@s3h.nust.edu.pk

**The author is Assistant Professor at Tapia College of Business, Saint Leo University, United States. He can be contacted at: zacharyasmith@gmail.com

@ 2021 by the Islamabad Policy Research Institute.

IPRI Journal $\square$ XXI (1): 27-59

https://doi.org/10.31945/iprij.210102

IPRI JOURNAL -2021 


\section{Introduction}

$\mathrm{C}$

orruption is considered as one of the major obstacles confronting developing nations as it severely impedes economic development and a nation's welfare. In general, corruption leads to the misappropriation of government funds, poor governance and political instability. Previous studies ${ }^{1} 2{ }^{3}$ report that corruption distorts economic activities, which reduces foreign investment. This leads to excessive government expenditures, distracts states from primary goals of lowcost/efficient public projects, and eventually increases the possibilities of bribery and manipulation. "Corruption is much more likely to flourish where democratic foundations are weak so as undemocratic and populist politicians can use it to their advantage." As per the United Nations Human Development Indicators (HDI), countries with the lowest scores in terms of human development, also receive low scores on the Transparency International (TI) corruption index. ${ }^{5}$ The researchers empirically examined the effect of corruption on economic growth and found a statistically significant relationship between them.

The level of corruption in Asian countries fluctuates primarily due to the strength of their institutional base, excessive external aid, low levels of FDI, and economic freedom. ${ }^{6}{ }^{78}$ Government spending in Asian

${ }^{1}$ Paolo Mauro, “Corruption and growth,” The Quarterly Journal of Economics 110, no. 3 (1995): 681-712, doi: $10.2307 / 2946696$

${ }^{2}$ Shang-Jin Wei, "Corruption in economic development - beneficial, grease, minor annoyance, or major obstacles?” Policy Research Working Paper 2048, The World Bank.

${ }^{3}$ d'Agostino, Giorgio John Dunne and Luca Pieroni, "Government spending, corruption, and economic growth," World Development 84, no. C (2016): 190-205, doi: 10.1016/j.worlddev.2016.03.011.

${ }^{4}$ Delia Ferreira Rubio, "How corruption weakens democracy," Transparency International (2018). https://www.transparency.org/en/news/cpi-2018-global-analysis

5 d'Agostino, Giorgio John Dunne and Luca Pieroni, "Corruption and growth in Africa," European Journal of Political Economy 43 (2016), 71-88, doi: 10.1016/j.ejpoleco.2016.03.002.

${ }^{6}$ Shang-Jin Wei, "Corruption in economic development - beneficial, grease, minor annoyance, or major obstacles?” Policy Research Working Paper 2048, The World Bank.

${ }^{7}$ Kwabena Gyimah-Brempong and Samaria Munoz de Gyimah-Brempong, "Corruption, growth, and income distribution: Are there regional differences," Economics of Governance 7, no. 3, (2006): 245-269. 
Impact of Corruption on Economic Growth: Evidence from Asian ..

countries is also an important concern considering the prevalence of greedy countries and elites. ${ }^{9}$ Previous studies ${ }^{10} 11 \quad 12$ report that corrupt states indulge in higher government spending when compared against non-corrupt states; additionally, the magnitude of government spending is another factor that inflates the likelihood of corruption in some countries. Earlier studies ${ }^{13} 14 \quad 15$ posit that the classifications of government expenditures lead to vulnerability in terms of the level of corruption. One classification of government spending that seems to cause unethical behaviour is military expenditures. The opaque procedures used to allocate defence contracts can generate rent-seeking behaviour. Researchers ${ }^{16}$ agree that excessive expenditure on defence leads to rentseeking behaviour and limited investment in the private sector.

${ }^{8}$ Chiung-Ju Huang, "Is corruption bad for economic growth? Evidence from Asia-Pacific countries," North American Journal of Economics and Finance 35, no. 1 (2016): 247256, doi: 10.1015/j.najef.2015.10.013.

${ }^{9}$ Nava Kahana and Liu Qijun, "Endemic corruption," European Journal of Political Economy 26, no.1 (2010): 82-88, doi:10.1016/j.ejpoleco.2009.09.001.

${ }^{10}$ Carlos Leite and Jens Weidmann, "Does mother nature corrupt? Natural resources, corruption, and economic growth," IMF Working Paper no. 99/85 (1999).

${ }^{11}$ Andrew Hodge, Sriram Shankar, D.S. Prasada Rao and Alan Duhs, "Exploring the links between corruption and growth," Review of Development Economics 15, no. 3, (2011): 474-490, doi: 10.1111/j.1467-9361.2011.00621.x.

${ }^{12}$ Chiung-Ju Huang, "Is corruption bad for economic growth? Evidence from Asia-Pacific countries," North American Journal of Economics and Finance 35, no. 1 (2016): 247 256, doi: 10.1015/j.najef.2015.10.013.

${ }^{13}$ Vito Tanzi, "Corruption around the world: Cause, consequences, scope, and cures," IMF Working Paper 45, no. 4 (1998), 559-594.

${ }^{14}$ David de la Croix and Clara Delavallade, "Growth, public investment and corruption with failing institutions," Economics of Governance 10, no. 3 (2009): 187-219.

${ }^{15}$ d'Agostino, Giorgio John Dunne and Luca Pieroni, "Corruption, military spending and growth," Defence \& Peace Economics 23, no. 6 (2012): 591-604, doi: 10.1080/10242694.2012.663579.

${ }^{16}$ d'Agostino, Giorgio John Dunne and Luca Pieroni, "Corruption, military spending and growth," Defence \& Peace Economics 23, no. 6 (2012): 591-604, doi: 10.1080/10242694.2012.663579. 
This study examines how corruption relates to government expenditures and affects economic growth in Asian countries. We consider 42 Asian economies from 1996 to 2018 and explore the relationship between aggregate government expenditures and corruption. Initially, we follow the endogenous growth model by incorporating different forms of government expenditures and corruption. Next, we develop an empirical framework to test our propositions. The results confirm that corruption considerably deters economic growth in Asia. We may interpret this as evidence that the traits of organisations can affect economic development as the government expenditures are influenced by corruption, which leads to rent-seeking activities and cause an increase in corruption.

Rest of the paper is structured as follows: Section 2 presents a brief literary review. Section 3 explains the endogenous growth model by incorporating various forms of government spending and corruption. Section 4 develops an empirical framework. Section 5 provides the empirical results, and Section 6 concludes the paper.

\section{A review of the earlier studies}

Examination of the association between corruption and economic growth has been an interest of the academician and researchers for some time. To explore whether corruption affects economic growth, earlier literature examines this relationship across countries and time. In a cross-country analysis, a researcher ${ }^{17}$ employed corruption as the extent to which business transactions indulged in corrupt practices and reported that corruption adversely affects the ratio of investment to GDP thereby restricting economic activities. Other studies ${ }^{18}{ }^{19}$ also suggest that corruption has an inverse and significant influence on economic growth. Likewise, researchers ${ }^{20}{ }^{21}$ argue that corrupt practices severely affect a

\footnotetext{
${ }^{17}$ Paolo Mauro, “Corruption and growth," The Quarterly Journal of Economics 110, no. 3 (1995): 681-712, doi: 10.2307/2946696.

${ }^{18}$ Helene Poirson, "Economic security, private investment and growth in developing countries," IMF Working Paper 98/4 (1998).

${ }^{19}$ Carlos Leite and Jens Weidmann, "Does mother nature corrupt? Natural resources, corruption, and economic growth," IMF Working Paper no. 99/85 (1999).

${ }^{20}$ Vito Tanzi, "Corruption around the world: Cause, consequences, scope, and cures," IMF Working Paper 45, no. 4 (1998),
} 
Impact of Corruption on Economic Growth: Evidence from Asian ..

country's competitiveness, as it reduces foreign investment and economic growth while leading them to spend excessively, misuse funds and poorly allocate resources.

To measure the relationship between corruption and growth, a researcher ${ }^{22}$ considered four survey-based indices of 'corruption perceptions' and a sample of 13 Asian and 10 non-Asian countries. $\mathrm{He}$ argued that higher corruption leads to lower economic development. However, various spending channels indicate that corruption affects economic development through many channels (i.e., decrease in foreign investment, excessive government spending, and affecting the mix of government expenditures). Further, he reported that many countries are trapped in a vicious circle of corruption which negatively influences economic growth. Countries with comparatively large public sectors face severe corruption challenges based on the higher level of state involvement in public markets.

Another researcher ${ }^{23}$ used 54 countries during the 1960 to 1985 period to investigate this association and reported that the corruption index, human capital, political instability and population growth rate significantly influence the per capita GDP. He determined that corruption exists due to institutional inefficiency (e.g., exhaustive legislative and judicial system and excessive bureaucracy by red-tapism). Further, a

${ }^{21}$ Susan Rose-Ackerman, "Corruption and government: Causes, consequences, and reform," Cambridge: Cambridge University Press. (1999), doi: 10.1017/CBO978113917509.

${ }^{22}$ Shang-Jin Wei, "Corruption in economic development - beneficial, grease, minor annoyance, or major obstacles?" Policy Research Working Paper 2048, The World Bank.

${ }^{23}$ Pak Hung Mo, "Corruption and economic growth," Journal of Comparative Economics 29, no. 1 (2001): 66-79, doi: 10.1006/jcec.2000.1703. 


\section{Dr. Muhammad Zubair Mumtaz \& Dr. Zachary A. Smith}

researcher ${ }^{24}$ indicated that corruption slows down economic activities because countries pursue ineffective investments in public projects and face a reduction in the magnitude of foreign inflows. Similarly, using the sample of 81 countries during the period lasting from 1984 to 2005, researchers ${ }^{25}$ argued that corruption retards growth which influences physical investment, human capital and political instability. Finally, it is reported a negative association between corrupt practices and economic activities is caused by political instability. ${ }^{26}$

In another study, researchers ${ }^{27}$ indicated that corruption in Africa is systematic like many other countries. However, it influences economic activities differently than other regions due to the prevalence of weak institutional systems, reliance on external aid, low levels of FDI, less economic freedom and small private industrial sectors. In another study, researchers ${ }^{28}$ examined the effect of corruption on growth using 47 African countries during the period lasting from 1996 to 2010. They employ three proxies of corruption (i.e., World Bank corruption index, ICRG, and TI) and reported that corrupt practices harm economic growth in the sample countries. Furthermore, they indicate that autocratic regimes, lower economic growth, and abundant natural resources lead to higher economic growth. Using a sample of 106 countries during the 1996 to 2010 period, researchers ${ }^{29}$ analysed the impact of corruption and military spending on economic growth. They report that investment spending spurs economic growth whereas military spending, government consumption, and high levels of corruption negatively influence growth.

${ }^{24}$ Ahmed Audu Maiyaki, "The effects of corruption on the Nigerian economy," Business Review 5, no. 2 (2010): 111-126.

${ }^{25}$ Andrew Hodge, Sriram Shankar, D.S. Prasada Rao and Alan Duhs, "Exploring the links between corruption and growth," Review of Development Economics 15, no. 3, (2011): 474-490, doi: 10.1111/j.1467-9361.2011.00621.x.

${ }^{26}$ Mohamed Dridi, "Corruption and economic growth: The transmission channels," Journal of Business Studies Quarterly 4, no. 4 (2013): 121-152.

${ }^{27}$ L. Pieroni, L. and G. d'Agostino, "Corruption and the effects of economic freedom. European Journal of Political Economy 29 (2013): 54-72, doi: 10.1016/j.ejpoleco.2012.08.002.

${ }^{28}$ d'Agostino, Giorgio John Dunne and Luca Pieroni, "Corruption and growth in Africa," European Journal of Political Economy 43 (2016), 71-88, doi: 10.1016/j.ejpoleco.2016.03.002.

${ }^{29}$ d'Agostino, Giorgio John Dunne and Luca Pieroni, "Government spending, corruption, and economic growth," World Development 84, no. C (2016): 190-205, doi: 10.1016/j.worlddev.2016.03.011. 
Impact of Corruption on Economic Growth: Evidence from Asian ..

Most empirical studies are in agreement that corruption has a negative influence on economic growth. However, some studies identify the positive association between corruption and economic growth. ${ }^{30}$ In this context, researchers argue that corruption intensifies the governmental efficacy which reduces transaction costs, thereby affecting the performance of economies. Earlier studies ${ }^{31} 32$ demonstrated that when a country is engaged in maximising national output, it leads to an optimal level of corruption. Researchers ${ }^{33}$ argued that in a few developing countries, corruption helps to eradicate specific causes that restrict growth. In another study, a researcher ${ }^{34}$ considered 13 Asian-Pacific countries between 1997 and 2013 to investigate the relationship. $\mathrm{He}$ employed a bootstrapping Granger causality approach and reported no evidence of an effect of corruption on the economic growth in the AsianPacific countries, except for South Korea.

Considering the perception that corruption is not conducive for economic growth, some researchers' document that level of corruption can increase growth in certain cases. ${ }^{35} 36{ }^{37}$ Some argue an inconclusive

\footnotetext{
${ }^{30}$ Chiung-Ju Huang, "Is corruption bad for economic growth? Evidence from Asia-Pacific countries," North American Journal of Economics and Finance 35, no. 1 (2016): 247256, doi: 10.1015/j.najef.2015.10.013.

${ }^{31}$ Robert Klitgaard, “Controlling corruption,” Berkley: University of California Press (1991).

${ }^{32}$ Daron Acemoglu and Thierry Verdier, "Property rights, corruption and the allocation of talent: A general equilibrium approach," The Economic Journal 108 (1998): 1381-1403.

${ }^{33}$ Enrico Colombatto, "Why is corruption tolerated? The Review of Austrian Economics 16, no. 4 (2003): 363-379.

${ }^{34}$ Chiung-Ju Huang, "Is corruption bad for economic growth? Evidence from Asia-Pacific countries," North American Journal of Economics and Finance 35, no. 1 (2016): 247256, doi: 10.1015/j.najef.2015.10.013.

${ }^{35}$ Enrico Colombatto, "Why is corruption tolerated? The Review of Austrian Economics 16, no. 4 (2003): 363-379.

${ }^{36}$ Mushfiq Swaleheen, "Economic growth with endogenous corruption: An empirical study," Public Choice 146 (2011): 23-41.

${ }^{37}$ Chiung-Ju Huang, "Is corruption bad for economic growth? Evidence from Asia-Pacific countries," North American Journal of Economics and Finance 35, no. 1 (2016): 247256, doi: 10.1015/j.najef.2015.10.013.
} 
relationship between corruption and growth ${ }^{38} 39$ and others report the existence of a negative association between corruption and economic performance. ${ }^{40}{ }^{41}$ As the empirical findings report an ambiguous relationship between corruption and economic growth, this study attempts to explore the same relationship by analysing 42 Asian economies from 1996 to 2018. The purpose of analysing Asian economies is that most of the countries were ranked below average according to the Corruption Perception Index in 2018. This implies that according to the index, these countries have, on average, higher levels of corruption. To address this concern, we examine how corruption affects growth in Asia.

\section{Modeling framework}

This study follows the growth model with an assumption that a typical agent with utility $U$ by selecting a consumption pattern at time $\mathrm{t}\left(c_{t}\right)$, expressing the policy rate as $\rho$ and specified a utility function as $u\left(c_{t}\right)=$ $\frac{\left(c_{t}^{1-\sigma}-1\right)}{(1-\sigma)}$, the agent amplifies the function as. ${ }^{42}$

$$
U=\int_{0}^{\infty} u\left(c_{t}\right) e^{-\rho t} d t
$$

With the constant returns to scale, the Cobb-Douglas function can be written as:

\footnotetext{
${ }^{38}$ Edward L. Glaeser and Raven E. Saks, "Corruption in America," Journal of Public Economics 90, no. 6/7 (2006): 1053-1072, doi: 10.1016/j.jpubeco.2005.08.007.

${ }^{39}$ Daniel Treisman, What have we learned about the causes of corruption from ten years of crossnational empirical research? Annual Review of Political Science 10 (2007): 211-244, doi: 10.1146/annurev.polisci.10.081205.095418.

40 Daron Acemoglu and Thierry Verdier, "Property rights, corruption and the allocation of talent: A general equilibrium approach," The Economic Journal 108 (1998): 1381-1403.

${ }^{41}$ Ratbek Dzhumashev, "Corruption and growth: The role of governance, public spending, and economic development," Economic Modelling 37 (2014): 202-215.

${ }^{42}$ Robert J. Barro, "Government spending in a simple model of endogenous growth," Journal of Political Economy 98, no. 5 (1990): S103-S125.
} 
Impact of Corruption on Economic Growth: Evidence from Asian ..

$$
y_{t}=f\left(k_{t}, g_{i t}\right)=A k_{t}^{1-\alpha-\beta-\delta} g_{1 t}^{\alpha} g_{2 t}^{\beta} g_{3 t}^{\delta}
$$

Where $y_{t}$ refers to output, $k_{t}$ is physical capital, and government spending include military spending $\left(g_{1 t}\right)$, government investments $\left(g_{2 t}\right)$, and government consumption $\left(g_{3 t}\right)$. The $\alpha, \beta$, and $\delta$ represent the input components related to government spending. Under this framework, public spending is valuable as it is a determinant of production presumed to be exogenous at a stable income tax rate, $\tau$ which is reflected as:

$$
G_{t}=\tau y_{t}, 0<\tau<1
$$

The notation $\tau=\frac{G_{t}}{y_{t}}$ shows the proportion of government spending relative to output, that is, the proportion of the government's size in an economy. Generally, the government collects taxes $\left(\tau y_{t}\right)$ to fund spending $G$. We distinguish different governments and their respective tax policies over time as follows:

$$
g_{i}=\phi_{i} \tau y_{t}
$$

Where $\phi_{i}$ represents the participation of government spending distributed to the $i$ th government's expenditures. A researcher ${ }^{43}$ argued that government spending is worthwhile if it influences economic growth; however, diverse government spending may have a different effect. Precisely, $\phi_{1}, \phi_{2}$, and $\phi_{3}$ are expressed as the proportion of government expenditures relative to total expenditures across countries. We incorporate corruption into the growth equation as a comparative tax on income $^{44}$ because we presume that various types of corruption may influence the efficiency of inputs and the growth rate in an identical

${ }^{43}$ Robert J. Barro, "Government spending in a simple model of endogenous growth," Journal of Political Economy 98, no. 5 (1990): S103-S125.

${ }^{44}$ Paolo Mauro, “Corruption and growth," The Quarterly Journal of Economics 110, no. 3 (1995): 681-712, doi: 10.2307/2946696. 
manner. This equation classifies three dimensions of spending, which eventually permits corruption to behave in different ways. We consider $h_{1}, h_{2}$, and $h_{3}$ to identify components that roughly influence corruption and its impact on the productivity of government spending. Their values fall between 0 , where corruption-related events influence the efficiency of government spending, and 1, where the government complies with the rules regarding the distribution of expenditure.

$$
\begin{aligned}
g_{1 h} & =h_{1} \phi_{1} \tau y_{t} \\
g_{2 h} & =h_{2} \phi_{2} \tau y_{t} \\
g_{3 h} & =h_{3}\left(1-\phi_{1}-\phi_{2}\right) \tau y_{t}
\end{aligned}
$$

Considering the Equations $(2 \& 3)$ and $(5,6, \& 7)$ which illustrate that at present the agent bears the budget restriction provided by the capital accumulation function, we propose the following:

$$
\begin{aligned}
\dot{k} & =y_{t}-\left(g_{1 h t}+g_{2 h t}\right)-c_{t} \\
& =(1-\tau) A k_{t}^{1-\alpha-\beta}\left(h_{1} \phi_{1}\right)^{\alpha}\left(h_{2} \phi_{2}\right)^{\beta}\left[h_{3}\left(1-\phi_{1}-\phi_{2}\right)\right]^{\delta}\left(\tau y_{t}\right)^{\alpha+\beta+\delta} c_{t}
\end{aligned}
$$

and maximises 1 with regard to $c_{t}$ and Eq. (8). The subsequent Hamiltonfunction is written as:

$$
\begin{gathered}
H=c\left(c_{t} e^{\rho t}\right)+(1-\tau) A k_{t}^{1-\alpha-\beta}\left(h_{1} \phi_{1}\right)^{\alpha}\left(h_{2} \phi_{2}\right)^{\beta}\left[h _ { 3 } \left(1-\phi_{1}-\right.\right. \\
\left.\left.\phi_{2}\right)\right]^{\delta}\left(\tau y_{t}\right)^{\alpha+\beta+\delta}-c_{t}
\end{gathered}
$$

and utilising the basis that the tax rate $\tau$ is assumed as stable in the unvarying equation $k_{t}$, thus the growth model is reflected as: 
Impact of Corruption on Economic Growth: Evidence from Asian ..

$$
\begin{aligned}
& \frac{\dot{c}}{c}=\xi=\frac{1}{\sigma}\left[j\left(h_{1} \phi_{1}\right)^{\frac{\alpha}{1-\alpha-\beta-\delta}}\left(h_{2} \phi_{2}\right)^{\frac{\beta}{1-\alpha-\beta-\delta}}\left[h_{3}\left(1-\phi_{1}-\phi_{2}\right)\right]^{\frac{\delta}{1-\alpha-\beta-\delta}}-\right. \\
& \rho]
\end{aligned}
$$

where $j=(1-\alpha-\beta-\delta)(1-\tau) A^{\frac{1}{1-\alpha-\beta-\delta}} \tau^{\frac{\alpha+\beta+\delta}{1-\alpha-\beta-\delta}}$ and $\xi$ estimates the output growth rate. The partial derivative of $\xi$ in terms of $\phi_{i}$ gauges the 'gross impact' pertaining to spending made by the government on growth as:

$$
\begin{aligned}
& \text { (i) } \frac{\partial \xi}{\partial \phi_{1}} \geq 0 \text { if } \frac{\phi_{1}}{\left(1-\phi_{1}\right)} \leq \frac{\alpha}{\beta+\delta} \\
& \text { (ii) } \frac{\partial \xi}{\partial \phi_{1}}<0 \text { if } \frac{\phi_{1}}{\left(1-\phi_{1}\right)}>\frac{\alpha}{\beta+\delta}
\end{aligned}
$$

The variation in the output elasticities of the parameters associated with spending and the proportion of government expenses influence economic growth. When we employ the direct and indirect impacts, we presume an inverse association between economic growth and corruption. The distinct derivative of $\hat{\imath}$ in terms of $\phi_{1}$ and $h_{1}$ can be expressed as:

$$
\begin{aligned}
& \text { (i) } \frac{\partial \xi}{\partial \phi_{1}} \geq 0 \quad \mid \frac{\partial \xi}{\partial h_{1}}<0 \Rightarrow \frac{\partial^{2} \xi}{\partial \phi_{1} \partial h_{1}} \leq 0 \\
& \text { (ii) } \frac{\partial \xi}{\partial \phi_{1}}<0 \quad \mid \frac{\partial \xi}{\partial h_{1}}<0 \Rightarrow \frac{\partial^{2} \xi}{\partial \phi_{1} \partial h_{1}}>0
\end{aligned}
$$

The probable indications of the gross and indirect association between the parameters are shown in Equation (11). In addition, this model supposes that ineffectiveness caused by corruption is trivial for present government expenses, referring to Equation (7) where $h_{3} \cong 1$. 


\section{Empirical modeling and data}

To evaluate the growth model, we first develop the conventional model as:

$$
\xi_{i t}=\varpi_{0}+\varpi_{1} X_{i t}^{1}+v_{i}+\eta_{t} \varepsilon_{i t}
$$

where $i$ and $t$ refer to each country and time period respectively. $\xi_{i t}$ denotes the average growth rate of GDP for country $i$ at time $t . X_{i t}^{1}=$ $\left[\right.$ mil $_{i t}$, inv $_{i t}$, Cons $_{i t}$, corr $\left._{i t}\right]$ is the vector of covariates. $v_{i}$ are unobserved country effects, and $\eta_{t}$ show time-specific effects. We assume that the control variables are not exogenous so there is a possibility that they may be inter-related with $\varepsilon_{i t}$ and this concern needs to be accounted for while evaluating the model. Furthermore, the theoretical model elaborates on the provision of out-of-steady-state dynamics, which generates connectivity issues for $A$ in Equation (2). Since there are differences in the production functions of countries that lead to differences in technological advancement we added as a part of the residuals and related to initial per capita income growth, that is, $\varepsilon_{i t}=f(A)$. To circumvent this problem, $A$ is demonstrated as $A=\varpi_{2} \xi_{i t-1}+\varepsilon_{i t}^{*}$, represented in Equation (13). In

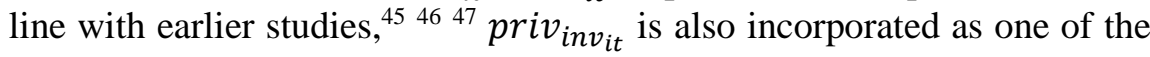
determinants which attempt to capture the existence of a relationship between foreign investment and corruption:

$$
\xi_{i t}=\alpha+\varpi_{1}^{I} X_{i t}^{1}+\varpi_{2} \xi_{i t-1}+\varpi_{3} \operatorname{priv}_{i n v_{i t}}+v_{i}+\eta_{t}+\mu_{i t}
$$

\footnotetext{
${ }^{45}$ Robert J. Barro, "Government spending in a simple model of endogenous growth," Journal of Political Economy 98, no. 5 (1990): S103-S125.

${ }^{46}$ Peter Eagger and Hannes Winner, "Evidence on corruption as an incentive for foreign direct investment," European Journal of Political Economy 21, no. 4 (2005): 499-547, doi: 10.1016/j.ejpoleco.2005.01.002.

47 d'Agostino, Giorgio John Dunne and Luca Pieroni, "Corruption and growth in Africa," European Journal of Political Economy 43 (2016), 71-88, doi: 10.1016/j.ejpoleco.2016.03.002.
} 
Impact of Corruption on Economic Growth: Evidence from Asian ..

where $\mu_{i t}$ is the error term comprising $\varepsilon_{i t}$ and $\varepsilon_{i t}^{*}$. To estimate Equation (13), this study considers 42 Asian economies lasting from 1996 to 2018 to model the association between government spending, corruption, and economic growth. $X^{1}$ represents government spending and by distinguishing government expenditure from military expenditure, gross domestic fixed investment, government consumption, expenditures, and the proportion of gross private investment in GDP. In terms of corruption, we use the control of corruption $\left(C C I_{\text {corr }}\right)$ variable which was devised based on an assessment of countries and their magnitude of public power that is used for private gain. This index ranges between 0 and 100, where 0 refers to a higher probability of corruption. Alternatively, we employ the corruption index (ICRG $\left.G_{c o r r}\right)$ and the value of index ranging from 0 to 100, where 100 refers to a higher magnitude of corruption. Lastly, Transparency International $\left(T I_{\text {corr }}\right)$ is similar to $C C I_{\text {corr }}$ - an index of corruption whereas the substitute measures are employed for robustness.

To extend the analysis, we incorporate different control variables that elaborate on the specific strategic and institutional parameters, which are expected to be pertinent for the Asian countries. The model is written as:

$$
\xi_{i t}=\alpha+\varpi_{1}^{I} X_{i t}^{1}+\varpi_{2} \xi_{i t-1}+\varpi_{3} \text { priv }_{i n v_{i t}}+\varpi_{4}^{k} X_{i t}^{2}+v_{i}+\eta_{t}+\mu_{i t}
$$

where $X_{i}^{2}=\left[\right.$ regime $_{i}$, resources $\left._{i}\right]$ refers to the set of variables that highlight the system of government and stock of natural resources. Countries can devise their policies in a way that influences economic growth. These arrangements can be discussed from the perspective of 
democratic and autocratic regimes. Researchers ${ }^{48}$ reported that the distribution of resources of the autocratic regime is generally tilted toward military spending when compared against a democratic regime. Whereas, it is argued that electoral incentives related to policies followed by democratic regimes encourage consumption over investment to a larger extent when compared against an autocratic regime. ${ }^{49}$ To estimate the type of government, we use the Polity IV database. This index considers the various degrees of autocracy by allocating diverse institutional dimensions. The index shows that a score of -10 is fully autocratic and a score of 10 is fully democratic. In this study, we use the exports of primary commodities divided by total exports, which indicate the natural resources in a given country. We measure it as a dummy variable i.e., $1=$ the value is more than the average of the sample countries and 0 otherwise. To eliminate the possibility that any variables are constant over time, we postulate Equation (14):

$$
\Delta \xi_{i t}=\varpi_{1}^{I} \Delta X_{i t}^{1}+\varpi_{2} \Delta \xi_{i t-1}+\varpi_{3} \Delta \operatorname{priv}_{i n v_{i t}}+\varpi_{4}^{k} \Delta X_{i t}^{2}+\mu_{i t}-\mu_{i t-1}
$$

where $X_{i t}^{1}=\left[\right.$ mil $_{i t}$, inv $_{i t}$, cons $\left._{i t}, \operatorname{corr}_{i t}\right], X_{i}^{2}=\left[\right.$ regime $_{i}$, resources $\left._{i}\right]$ and $\operatorname{priv}_{i n v_{i t}}$ is a proportion of private investment in GDP. We use a GMM estimation technique that is distinct from the traditional Hansen test statistics. In this study, we evaluate supplementary regressions using a set of variables $\left[\mathrm{mil}_{i t}\right.$, inv $\left._{i t}, \mathrm{cons}_{i t}, \operatorname{corr}_{i t}\right]$ with $\operatorname{corr}_{i t}$ indicating the generic parameter of corruption. In the context of the system GMM technique, the gross elasticities are measured as:

$$
x_{1} e_{\operatorname{gross} \xi}=\varpi_{1}^{/} \tilde{X}^{/ /}(\ldots)
$$

where $\tilde{X}^{/ /}{ }_{(\ldots)}=\left[\frac{\bar{m} i l}{\bar{\xi}}, \frac{\bar{n} v}{\bar{\xi}}, \frac{c \bar{o} r r}{\bar{\xi}}\right]$ and $\varpi_{1}^{I=1, \ldots 3}=\left[\varpi_{m i l}, \varpi_{i n v}, \varpi_{c o r r}\right]$ is a vector of components evaluated employing Equation (16). To measure

\footnotetext{
${ }^{48}$ Karim Khan, Saima Batool and Anwar Shah, "Authoritarian regimes and economic development: An empirical reflection," Pakistan Development Review 55, no. 4 (2016): 657-673.

49 Vaman Rao, "Democracy and economic development," Studies in Comparative International Development 19 (1984): 67-81.
} 
Impact of Corruption on Economic Growth: Evidence from Asian ..

the gross elasticity, we consider the military parameter of government spending as an example which can be expressed as: ${ }_{m i l} e_{\text {gross }}=$ $\varpi_{m i l} \frac{\bar{m} i l}{\bar{\xi}}$. We measure indirect elasticities (e.g., spending factor) as:

$$
m i l_{i t}=a+b_{1} i n v_{i t}+b_{2} \operatorname{corr}_{i t}+v_{i}+\eta_{t}+f_{i t}
$$

The variables measured through Equations (16) and (17) are utilised to get the indirect elasticity for military spending: mil.corr $_{i n d}=\left(\varpi_{\text {corr }} b_{2}\right) \frac{\bar{m} i l}{\bar{\xi}}$. Lastly, the net elasticity $=$ gross + indirect elasticities and measured as ${ }_{m i l} e_{n e t_{\xi}}={ }_{m i l} €_{\text {gross }_{\xi}}+\frac{m_{\text {il }}}{\text { corr }_{\text {ind }}}+\frac{\text { mil }}{{ }_{\text {inv }} e_{\text {ind }}}$. To evaluate the growth model, we first develop the conventional model. After the diagnostic tests, in this study, we use both OLS and GMM techniques to estimate our analysis.

\section{Empirical Analysis}

\section{Summary statistics}

Table 1 shows the summary statistics of the variables used in this study during the sample period lasting from 1996 to 2018. This study covers a sample of Asian economies and the results show that the mean value of the GDP per capita growth $(\xi)$ is $3.38 \%$. On average, the highest value of $\xi$ is $8.57 \%$ (Myanmar) followed by $8.48 \%$ (China) whereas a negative value is registered by the United Arab Emirates (-1.69\%). The mean value of $\xi$ is $4.09 \%$ and $2.15 \%$ in terms of low and military spending countries, respectively. We also find that a higher level of corruption and natural resources leads to higher economic growth.

On average, the share of private investment, GDP (privinv), is $18.81 \%$. India is the largest contributor towards privinv $(25.89 \%)$ and the lowest contributor is Timor-Leste (3.94\%). The results also indicate that 


\section{Dr. Muhammad Zubair Mumtaz \& Dr. Zachary A. Smith}

Asian countries with higher military spending contribute privinv $_{\text {inv }}=18.03 \%$. The magnitude of privinv is higher with countries that have less corruption and a higher level of natural resources. In terms of the military spending, GDP (mil), we find that the mean value is $2.92 \%$ which illustrates that in aggregate roughly three per cent is contributed towards military in Asian economies. The leading contributor of military is Oman (12\%) and the smallest share of military is Timor-Leste $(0.71 \%)$. The share of private investment in GDP is higher for those countries where corruption level and government investment are low. However, military is higher in the case of the autocratic regime.

Table-1

Summary Statistics (Average over time, 1996 - 2018)

\begin{tabular}{|c|c|c|c|c|c|c|c|c|c|c|}
\hline & $\xi$ & $p_{r i v}$ inv & mil & $i n v$ & cons & $\underset{r r}{C C I_{c o}}$ & $T I_{c o r r}$ & $\begin{array}{c}\text { ICRG } \\
\text { corr }\end{array}$ & $\begin{array}{l}\text { Reg } \\
\text { ime }\end{array}$ & $\begin{array}{l}\text { Reso } \\
\text { urces }\end{array}$ \\
\hline Afghanistan & 3.26 & 13.18 & 1.68 & 8.23 & 10.81 & 4.02 & 15.95 & - & 1.00 & 0.00 \\
\hline Armenia & 6.75 & 12.37 & 3.53 & 7.96 & 11.75 & 30.60 & 30.77 & 28.79 & 0.00 & 1.00 \\
\hline Azerbaijan & 7.71 & 22.06 & 3.23 & 7.47 & 11.80 & 10.24 & 22.32 & 28.41 & 1.00 & 1.00 \\
\hline Bangladesh & 4.17 & 20.05 & 1.30 & 3.53 & 5.19 & 14.71 & 18.59 & 37.88 & 0.00 & 1.00 \\
\hline Bahrain & 0.06 & 20.27 & 4.14 & 4.14 & 16.14 & 14.73 & 54.27 & 42.05 & 1.00 & 1.00 \\
\hline $\begin{array}{l}\text { Brunei } \\
\text { Darussalam }\end{array}$ & -0.80 & 7.24 & 3.68 & 3.24 & 23.43 & 69.73 & 55.91 & 45.83 & 1.00 & 0.00 \\
\hline Cambodia & 5.65 & 10.64 & 1.76 & 6.36 & 5.30 & 11.62 & 21.68 & - & 0.00 & 1.00 \\
\hline China & 8.48 & 25.02 & 1.92 & 4.04 & 14.15 & 42.09 & 34.68 & 32.20 & 1.00 & 1.00 \\
\hline Cyprus & 0.97 & 19.27 & 2.36 & 10.92 & 16.59 & 82.64 & 60.41 & 67.80 & 0.00 & 1.00 \\
\hline Georgia & 6.72 & 19.94 & 2.90 & 9.46 & 15.44 & 45.74 & 35.87 & - & 0.00 & 1.00 \\
\hline India & 5.38 & 25.89 & 2.67 & 5.23 & 11.06 & 42.49 & 32.14 & 42.05 & 0.00 & 1.00 \\
\hline Indonesia & 2.95 & 22.41 & 0.82 & 4.44 & 8.25 & 24.93 & 26.09 & 38.64 & 0.00 & 0.00 \\
\hline Iran & 2.02 & 20.85 & 2.37 & 8.74 & 11.50 & 33.18 & 27.82 & 39.39 & 1.00 & 1.00 \\
\hline Iraq & 5.07 & 9.27 & 2.80 & 2.19 & 17.05 & 4.27 & 18.48 & 17.80 & 1.00 & 0.00 \\
\hline Israel & 1.52 & 19.59 & 1.73 & 11.83 & 24.06 & 81.10 & 65.27 & 56.06 & 0.00 & 1.00 \\
\hline Japan & 0.86 & 18.70 & 0.94 & 10.10 & 18.36 & 87.73 & 71.64 & 62.50 & 0.00 & 0.00 \\
\hline Jordon & 0.90 & 18.79 & 5.45 & 7.96 & 21.47 & 61.24 & 51.55 & 52.27 & 1.00 & 1.00 \\
\hline Kazakhstan & 5.05 & 20.06 & 1.04 & 4.96 & 11.25 & 15.86 & 25.77 & 30.30 & 1.00 & 1.00 \\
\hline Kuwait & -0.79 & 23.18 & 5.54 & 4.21 & 21.74 & 65.57 & 47.41 & 45.08 & 1.00 & 1.00 \\
\hline Kyrgyzstan & 3.25 & 16.64 & 3.07 & 10.97 & 18.06 & 12.98 & 22.50 & - & 1.00 & 1.00 \\
\hline Laos & 5.38 & 17.29 & 0.97 & 4.61 & 9.96 & 15.79 & 27.91 & - & 1.00 & 1.00 \\
\hline Lebanon & 0.74 & 21.28 & 4.55 & 8.07 & 14.25 & 25.82 & 29.00 & 21.21 & 0.00 & 1.00 \\
\hline Malaysia & 2.87 & 14.72 & 1.85 & 7.52 & 12.42 & 63.41 & 49.05 & 45.08 & 0.00 & 1.00 \\
\hline Mongolia & 4.83 & 24.48 & 1.27 & 7.01 & 13.79 & 41.40 & 31.59 & 40.91 & 0.00 & 1.00 \\
\hline
\end{tabular}


Impact of Corruption on Economic Growth: Evidence from Asian ..

\begin{tabular}{|c|c|c|c|c|c|c|c|c|c|c|}
\hline Myanmar & 8.57 & 15.93 & 2.67 & 2.22 & 13.08 & 7.25 & 17.68 & 21.59 & 1.00 & 1.00 \\
\hline Nepal & 2.77 & 17.22 & 1.43 & 7.32 & 9.59 & 28.51 & 27.05 & - & 0.00 & 0.00 \\
\hline Oman & 0.01 & 11.93 & $\begin{array}{r}12.0 \\
0\end{array}$ & 5.31 & 22.08 & 69.82 & 55.14 & 45.45 & 1.00 & 1.00 \\
\hline Pakistan & 1.87 & 10.66 & 3.84 & 4.29 & 10.12 & 17.57 & 25.09 & 32.95 & 0.00 & 1.00 \\
\hline Philippines & 3.03 & 18.02 & 1.42 & 4.94 & 10.66 & 35.06 & 29.32 & 39.39 & 0.00 & 0.00 \\
\hline Qatar & 0.52 & 23.23 & 2.32 & 4.66 & 17.94 & 75.56 & 61.95 & 43.18 & 1.00 & 1.00 \\
\hline Saudi Arabia & 0.55 & 18.23 & 9.63 & 6.90 & 23.76 & 55.27 & 43.18 & 38.26 & 1.00 & 1.00 \\
\hline Singapore & 3.06 & 24.50 & 4.01 & 4.90 & 10.23 & 97.54 & 90.00 & 73.11 & 1.00 & 1.00 \\
\hline South Korea & 3.63 & 25.86 & 2.55 & 8.02 & 13.46 & 68.99 & 49.36 & 52.27 & 0.00 & 1.00 \\
\hline Sri Lanka & 4.50 & 20.35 & 3.29 & 3.94 & 11.01 & 48.97 & 35.32 & 49.24 & 0.00 & 0.00 \\
\hline Tajikistan & 3.97 & 8.02 & 1.12 & 7.08 & 12.12 & 8.63 & 20.41 & - & 1.00 & 0.00 \\
\hline Thailand & 2.60 & 18.36 & 1.53 & 6.32 & 14.54 & 46.28 & 34.36 & 32.58 & 0.00 & 1.00 \\
\hline Timor-Leste & 5.94 & 3.94 & 0.71 & 1.98 & 20.65 & 33.91 & 27.14 & - & 1.00 & 0.00 \\
\hline Turkey & 3.39 & 21.05 & 2.76 & 5.60 & 13.30 & 53.35 & 39.23 & 40.53 & 0.00 & 1.00 \\
\hline Turkmenistan & 6.10 & 21.43 & 3.00 & 5.56 & 10.90 & 5.83 & 19.09 & - & 1.00 & 0.00 \\
\hline $\begin{array}{l}\text { United Arab } \\
\text { Emirates }\end{array}$ & $1.69^{-}$ & 21.05 & 5.48 & 2.63 & 9.82 & 75.72 & 60.32 & 44.70 & 1.00 & 0.00 \\
\hline Uzbekistan & 4.49 & 21.97 & 1.06 & 6.14 & 17.93 & 10.62 & 20.00 & - & 1.00 & 0.00 \\
\hline Vietnam & 5.37 & 17.86 & 2.17 & 5.75 & 6.58 & 33.99 & 27.82 & 39.77 & 1.00 & 1.00 \\
\hline Sampl & 38 & 18.81 & 2.92 & 6.11 & 14.06 & 39.84 & 37.11 & 41.95 & 0.55 & 0.69 \\
\hline $\begin{array}{l}\text { Low military } \\
\text { spending } \\
\text { sample }\end{array}$ & 4.09 & 13.14 & 1.78 & 6.26 & 13.14 & 37.47 & 33.96 & 41.05 & 0.44 & 0.67 \\
\hline $\begin{array}{l}\text { High military } \\
\text { spending } \\
\text { sample }\end{array}$ & 2.15 & 18.03 & 4.96 & 5.84 & 15.17 & 44.11 & 42.79 & 42.10 & 0.73 & 0.73 \\
\hline $\begin{array}{l}\text { Low } \\
\text { Corruption } \\
\text { Sample } \\
\left(\text { CCI } I_{\text {corr }}\right)\end{array}$ & 2.23 & 19.75 & 3.75 & 6.55 & 16.65 & 64.77 & 51.13 & 48.17 & 0.47 & 0.79 \\
\hline $\begin{array}{l}\text { High } \\
\text { Corruption } \\
\text { Sample } \\
\left(C C I_{\text {corr }}\right)\end{array}$ & 4.34 & 16.86 & 2.23 & 5.75 & 11.51 & 19.24 & 25.53 & 32.87 & 0.61 & 0.61 \\
\hline $\begin{array}{l}\text { Low govt. } \\
\text { investment }\end{array}$ & 3.44 & 18.21 & 3.12 & 4.20 & 13.35 & 39.31 & 37.72 & 40.09 & 0.68 & 0.64 \\
\hline
\end{tabular}


Dr. Muhammad Zubair Mumtaz \& Dr. Zachary A. Smith

\begin{tabular}{|l|l|l|l|l|l|l|l|l|l|l|}
\hline $\begin{array}{l}\text { sample } \\
\text { High govt. } \\
\text { investment } \\
\text { sample }\end{array}$ & 3.33 & 18.21 & 2.70 & 8.21 & 14.84 & 40.43 & 36.44 & 43.50 & 0.40 & 0.75 \\
\hline $\begin{array}{l}\text { Low levels of } \\
\text { natural } \\
\text { resources }\end{array}$ & 3.13 & 15.60 & 2.11 & 5.21 & 13.89 & 33.69 & 32.85 & 42.59 & 0.62 & 0.00 \\
$\begin{array}{l}\text { High levels of } \\
\text { natural } \\
\text { resources }\end{array}$ & 3.50 & 19.32 & 3.28 & 6.51 & 14.13 & 42.60 & 39.02 & 41.17 & 0.52 & 1.00 \\
\hline $\begin{array}{l}\text { No-Autocratic } \\
\text { regimes }\end{array}$ & 3.44 & 18.98 & 2.24 & 6.98 & 12.57 & 44.71 & 37.41 & 42.99 & 0.00 & 0.74 \\
\hline $\begin{array}{l}\text { Autocratic } \\
\text { regimes }\end{array}$ & 3.34 & 17.50 & 3.48 & 5.39 & 15.28 & 35.82 & 36.86 & 39.96 & 1.00 & 0.65 \\
\hline
\end{tabular}

This table presents the summary statistics of 42 Asian economies during the period lasting from 1996 to 2018. The variables used in this study include: (a) $\xi=$ GDP/capita growth, (b) privinv $=$ private investment/GDP, (c) mil $=$ military spending/GDP, (d) inv = government investment/GDP, and (e) cons = government consumption/GDP. The regime is considered as a dummy variable where the type of government shows the value of 1 for the 'autocratic regime' and 0 for the 'democratic regime'. In terms of natural resources, we take the value of 1 for the countries with 'abundant natural resources' and 0 otherwise.

The share of government investment in GDP (inv), on average, is $6.11 \%$ with the highest and lowest value of $i n v=11.83 \%$ (Israel) and $2.19 \%$ (Iraq), respectively. The result shows that democratic regime countries contribute a higher proportion of government investment. On average, the government consumption/GDP (cons) contributes $14.06 \%$. There is a large variation in terms of government consumption among Asian economies. The proportion of government consumption is higher in those countries with high military spending that have an autocratic regime.

To gauge corruption, we use $C C I_{\text {corr }}, T I_{c o r r}$, and $I C R G_{c o r r}$. The mean value of $C C I_{\text {corr }}$ is 39.84. A higher value of $C C I_{\text {corr }}$ indicates a low level of corruption, while the lower value indicates a higher chance of corruption. From the results, it can be seen that the likelihood of corruption in Singapore is the lowest $\left(C C I_{\text {corr }}=97.54\right)$ while Afghanistan has the highest possibilities of corruption (4.02). By employing $T I_{c o r r}$, we find 
Impact of Corruption on Economic Growth: Evidence from Asian ..

similar results where Singapore and Afghanistan are categorised as low and high corruption countries, respectively. The parameters for measuring $I C R G_{\text {corr }}$ are different and suggest that Singapore is classified as a low corruption country and Iraq is the most corrupted country in the sample. Interestingly, we find that the likelihood of corruption in a democratic environment is higher.

\section{Primary evaluation}

Initially, we draw few scattered plots of GDP/capita growth against government expenditures and corruption (Figure 1). We construct them by regressing the GDP/capita growth on the main parameters (government expenditures, corruption) and other control parameters, eliminating the main parameters and subsequently outlining the residuals in terms of an eliminated parameter.

Panel (a) exhibits an insignificant relationship between the growth rate and government investment. Panel (b) demonstrates a downwardsloping relationship that illustrates that countries with higher military spending/ GDP have a lower per capita growth. ${ }^{50}$ Panel (c) has an even steeper downward curve which indicates that higher government consumption/GDP leads to a lower per capita growth rate. This study employs a proxy of corruption developed by the World Bank, Transparency Index, and ICRG to measure corruption. Panel (d) illustrates that countries with a higher level of corruption have a lower per capita rate (d'Agostino, et al, 2016b). We confirm this evidence using other measures of corruption [TI $I_{c o r r}$ (Panel-e) and ICRG $G_{c o r r}$ (Panel-f)].

\footnotetext{
${ }^{50}$ d'Agostino, Giorgio John Dunne and Luca Pieroni, "Corruption and growth in Africa," European Journal of Political Economy 43 (2016), 71-88, doi: 
To identify the relationship between the per-capital growth rate and the autocracy and natural resources variables, we use the non-parametric cross-country kernel estimates of density distribution exhibited in Figure 2. In terms of autocracy, we find a complicated association with growth which indicates lower levels of per capita growth and commonly indicates smaller tails. This demonstrates that in general, autocratic regimes would likely obtain lower per capital growth; however, it is argued that some of the democracies perform better than the others employed by earlier studies. ${ }^{51}{ }^{52}$ Interestingly, we find no difference in the growth rate concerning countries that have higher or lower levels of natural resources.
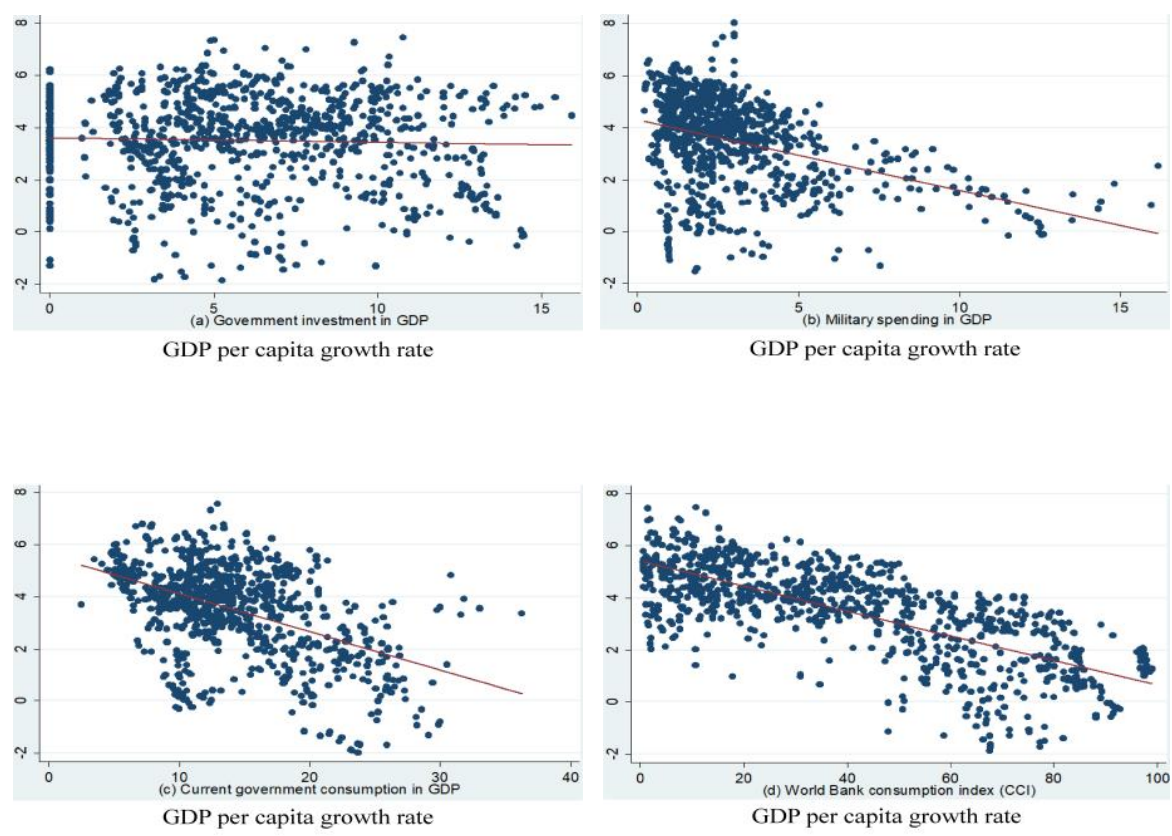

${ }^{51}$ d'Agostino, Giorgio John Dunne and Luca Pieroni, "Corruption and growth in Africa," European Journal of Political Economy 43 (2016), 71-88, doi: 10.1016/j.ejpoleco.2016.03.002.

52 Timothy Besley and Masayuki Kudamatsu, "Making autocracy work," CEPR Discussion Papers 6371 (2007). 

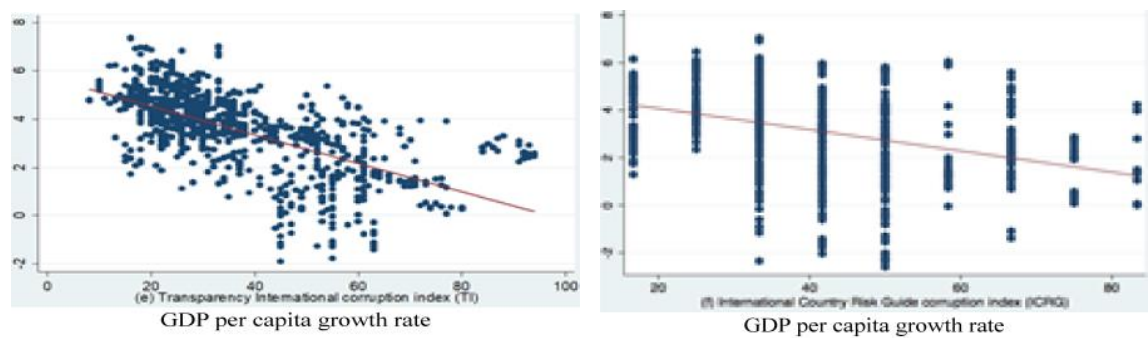

Figure 1: Partial scatterplots of the coefficient of growth rate against government expenditures and corruption
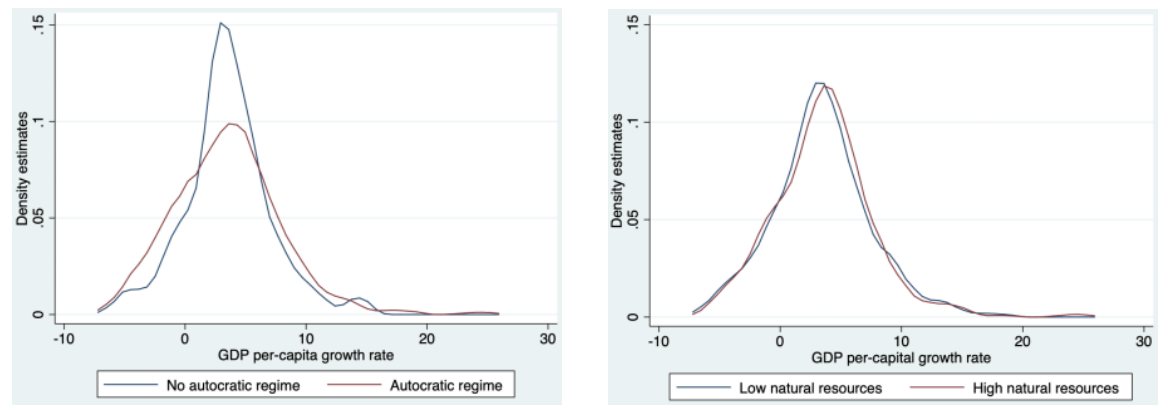

Figure 2: Density distributions: cross-countries estimates for selected control variables

\section{Examining the relationship between corruption and economic growth}

Table 2 exhibits the empirical findings of Equations (14) and (15) using the OLS estimates and the system GMM technique. We use the lagged value of private investment and government consumption expenditure in all specifications. In terms of different parameters of corruption, we 
separately observe their impact on growth. In all specifications, military spending/GDP shows a significant and adverse impact on growth which implies that higher military spending relative to GDP hurts growth in the country. The coefficient of government investment spending positively influences growth (Model II \& IV). This indicates that government investment creates opportunities for contributing towards productivity growth in a given country. priv inv $_{t-1}$ has an insignificant effect. Following the kernel estimates, the impact of natural resources has no impact on economic growth. In Model II, we report that an autocratic regime may positively affect the growth of Asian economies; however, in the rest of the models, the coefficient of the regime has no effect. This evidence is in line with an earlier study, ${ }^{53}$ which argues that economic performance was successful in Mexico in different periods of autocratic regimes. This implies that autocratic regimes partially imitate the main institutional characteristics of democracies.

In agreement with the model, the coefficient of the World Bank corruption index in Model I and II are negative [(-0.018), S.E. $=0.005 ;(-$ $0.192)$, S.E. $=0.083$ respectively]. The coefficient of the GMM model is roughly 11 times larger than POLS estimates. The results indicate that a higher level of corruption-related activities will not be reflected in the productivity growth of the country. In Models III and IV, we include Transparency International corruption index to examine the impact on GDP/ capita growth and report the same result obtained using the World Bank corruption index $[(-0.039)$, S.E. $=0.008 ;(-0.189)$, S.E. $=0.051$, respectively]. Likewise, we incorporate the ICRG corruption index in Model V and VI and find an inverse relationship between this index and the per-capital GDP growth rate [(-0.031), S.E. 0.010; $(-0.085)$, S.E. 0.044 , respectively].

\section{Multiple causation correlation}

To gauge the indirect effects of different spending on corruption, we estimate Equation (18) using the fixed effect panel data (Table 3) which 53 Jorg Faust, “Autocracies and economic development: Theory and evidence from $20^{\text {th }}$
century Mexico," Historical Social Research 32, no. 4 (2007): 305-329. 
Impact of Corruption on Economic Growth: Evidence from Asian ..

helps to simplify the static construction of the government budget constraints. The result indicates a direct association between military spending and the corruption index (Panel A), which implies that both variables supplement each other. Following the model, this evidence indicates that corruption increases the negative impact of the military sector on economic growth. In Panel B, we examine the effect of corruption and military spending on government investment spending. The coefficient of military spending is positive and significantly impacts government investment. This evidence is interesting; however, it generally argues that in all modes of government spending increases when there is increased growth in GDP. Moreover, it is hard to overcome investment and government spending in the presence of security issues. We do not find any evidence of a linkage between government investment and corruption. Panel $\mathrm{C}$ demonstrates the influence of military spending and government investment on corruption. We report that higher military spending leads to the possibility of increases in the level of corruption. As identified earlier, government investment spending does not affect corruption.

Table 4 shows the gross and net elasticities of the spending and corruption index $\left(C C I_{\text {corr }}\right)$.

Table-2

Estimation results: Dynamic panel data

\begin{tabular}{|c|c|c|c|c|c|c|}
\hline \multirow[b]{2}{*}{ Variables } & I & II & III & IV & V & IV \\
\hline & $\begin{array}{l}\text { Country- } \\
\text { fixed effect } \\
(\text { OLS })\end{array}$ & $\begin{array}{l}\text { System } \\
\text { GMM }\end{array}$ & $\begin{array}{l}\text { Country- } \\
\text { fixed } \\
\text { effect } \\
(\text { OLS) }\end{array}$ & $\begin{array}{l}\text { System } \\
\text { GMM }\end{array}$ & $\begin{array}{l}\text { Country- } \\
\text { fixed } \\
\text { effect } \\
(\mathrm{OLS})\end{array}$ & $\begin{array}{l}\text { System } \\
\text { GMM }\end{array}$ \\
\hline $\begin{array}{l}\text { GDP per capita } \\
\text { growth rate }_{t-1}\end{array}$ & $\begin{array}{l}0.396^{* * *} \\
(0.031)\end{array}$ & $\begin{array}{l}0.086^{*} \\
(0.050)\end{array}$ & $\begin{array}{l}0.378^{* * *} \\
(0.031)\end{array}$ & $\begin{array}{l}0.102^{* *} \\
(0.048)\end{array}$ & $\begin{array}{l}0.425^{* * *} \\
(0.035)\end{array}$ & $\begin{array}{l}0.076^{* * *} \\
(0.025)\end{array}$ \\
\hline $\begin{array}{l}\text { Private } \\
\text { investment }_{\mathrm{t}-1}\end{array}$ & $\begin{array}{l}0.026 \\
(0.018)\end{array}$ & $\begin{array}{l}0.167 \\
(0.109)\end{array}$ & $\begin{array}{l}0.032^{*} \\
(0.018)\end{array}$ & $\begin{array}{l}0.187^{* *} \\
(0.074)\end{array}$ & $\begin{array}{l}0.023 \\
(0.022)\end{array}$ & $\begin{array}{l}0.021 \\
(0.087)\end{array}$ \\
\hline $\begin{array}{l}\text { Military } \\
\text { spending/GDP }\end{array}$ & $\begin{array}{l}-0.173^{* * *} \\
(0.058)\end{array}$ & $\begin{array}{l}-0.489^{*} \\
(0.262)\end{array}$ & $\begin{array}{l}-0.167^{* * * *} \\
(0.057)\end{array}$ & $\begin{array}{l}-0.446^{*} \\
(0.262)\end{array}$ & $\begin{array}{l}-0.178^{* * *} \\
(0.066)\end{array}$ & $\begin{array}{l}-0.518^{*} \\
(0.289)\end{array}$ \\
\hline $\begin{array}{l}\text { Government } \\
\text { investment/GDP }\end{array}$ & $\begin{array}{l}0.006 \\
(0.035)\end{array}$ & $\begin{array}{l}0.156^{*} \\
(0.090)\end{array}$ & $\begin{array}{l}0.014 \\
(0.035)\end{array}$ & $\begin{array}{l}0.194^{* *} \\
(0.091)\end{array}$ & $\begin{array}{l}0.020 \\
(0.043)\end{array}$ & $\begin{array}{l}0.020 \\
(0.119)\end{array}$ \\
\hline $\begin{array}{l}\text { Current } \\
\text { government }\end{array}$ & $\begin{array}{l}-0.075^{* * *} \\
(0.026)\end{array}$ & $\begin{array}{l}-0.277^{* * *} \\
(0.079)\end{array}$ & $\begin{array}{l}-0.071^{* * *} \\
(0.025)\end{array}$ & $\begin{array}{l}-0.276^{* * *} \\
(0.077)\end{array}$ & $\begin{array}{l}-0.099^{* * *} \\
(0.030)\end{array}$ & $\begin{array}{l}-0.287^{* * *} \\
(0.108)\end{array}$ \\
\hline
\end{tabular}


Dr. Muhammad Zubair Mumtaz \& Dr. Zachary A. Smith

\begin{tabular}{|c|c|c|c|c|c|c|}
\hline consumption/GDP & & & & & & \\
\hline World Bank & $\begin{array}{l}-0.018^{* * *} \\
(0.005)\end{array}$ & $\begin{array}{l}-0.192^{* *} \\
(0.083)\end{array}$ & & & & \\
\hline $\begin{array}{l}\text { Transparency } \\
\text { International }\end{array}$ & & & $\begin{array}{l}-0.039^{* * *} \\
(0.008)\end{array}$ & $\begin{array}{l}-0.189^{* * *} \\
(0.051)\end{array}$ & & \\
\hline $\begin{array}{l}\text { International } \\
\text { Country Risk } \\
\text { Guide }\end{array}$ & & & & & $\begin{array}{l}-0.031^{\text {*** }} \\
(0.010)\end{array}$ & $\begin{array}{l}-0.085^{*} \\
(0.044)\end{array}$ \\
\hline Regimes & $\begin{array}{l}0.243 \\
(0.267)\end{array}$ & $\begin{array}{l}2.115^{*} \\
(1.287)\end{array}$ & $\begin{array}{l}0.402 \\
(0.256)\end{array}$ & $\begin{array}{l}1.584 \\
(1.265)\end{array}$ & $\begin{array}{l}0.270 \\
(0.309)\end{array}$ & $\begin{array}{l}0.657 \\
(1.363)\end{array}$ \\
\hline Resources & $\begin{array}{l}-0.085 \\
(0.237)\end{array}$ & $\begin{array}{l}-0.023 \\
(0.513)\end{array}$ & $\begin{array}{l}-0.091 \\
(0.235)\end{array}$ & $\begin{array}{l}0.003 \\
(0.553)\end{array}$ & $\begin{array}{l}-0.166 \\
(0.274)\end{array}$ & $\begin{array}{l}-1.075 \\
(0.735)\end{array}$ \\
\hline Time dummies & Yes & Yes & Yes & Yes & Yes & Yes \\
\hline $\begin{array}{l}\text { Second order } \\
\text { serial correlation } \\
\text { test }\end{array}$ & & -0.324 & & -0.821 & & -0.653 \\
\hline $\begin{array}{l}\text { Hansen test } \\
\text { statistics }\end{array}$ & & 35.46 & & 37.75 & & 29.97 \\
\hline $\begin{array}{l}\text { Number of } \\
\text { observations }\end{array}$ & 924 & 924 & 924 & 924 & 724 & 724 \\
\hline
\end{tabular}

Notes: To examine the effect of corruption on economic growth, this study estimates six models using both fixed-effect and system GMM techniques. We use three parameters of corruption to examine the impact on growth. The dependent variable is the growth rate of GDP $(\xi)$. The asterisk shows the significance level of $p$-values $\left({ }^{*} \mathrm{p}<0.1 ;{ }^{* *} \mathrm{p}<0.05 ;{ }^{* * *} \mathrm{p}<0.01\right)$.

Table-3

Multiple causation correlation: Fixed effect panel estimations

\begin{tabular}{|c|c|c|c|c|c|c|c|c|c|}
\hline \multirow{3}{*}{ Variables } & \multirow{2}{*}{\multicolumn{3}{|c|}{$\begin{array}{c}\text { Panel A: } \\
\text { Military spending/GDP }\end{array}$}} & \multirow{2}{*}{\multicolumn{3}{|c|}{$\begin{array}{c}\text { Panel B: } \\
\text { Government } \\
\text { investment/GDP }\end{array}$}} & \multicolumn{3}{|c|}{$\begin{array}{l}\text { Panel C: Corruption } \\
\text { index }\end{array}$} \\
\hline & & & & & & & $\begin{array}{l}\text { World } \\
\text { Bank }\end{array}$ & $\mathrm{TI}$ & ICRG \\
\hline & I & II & III & IV & V & VI & VII & VIII & IX \\
\hline $\begin{array}{l}\text { Military } \\
\text { spending/GDP }\end{array}$ & & & & $\begin{array}{l}0.554^{* *} \\
(0.078)\end{array}$ & $\begin{array}{l}0.553^{* * *} \\
(0.077)\end{array}$ & $\begin{array}{l}0.529^{* *} \\
(0.090)\end{array}$ & $\begin{array}{l}0.010^{* *} \\
(0.003)\end{array}$ & $\begin{array}{l}0.46 \\
1^{* *} \\
(0.1 \\
99)\end{array}$ & $\begin{array}{l}-0.086 \\
(0.456)\end{array}$ \\
\hline $\begin{array}{l}\text { Government } \\
\text { investment/ } \\
\text { GDP }\end{array}$ & $\begin{array}{l}0.103^{* * *} \\
(0.014)\end{array}$ & $\begin{array}{l}0.102^{* * *} \\
(0.015)\end{array}$ & $\begin{array}{l}0.099^{* * * *} \\
(0.017)\end{array}$ & & & & $\begin{array}{c}0.001 \\
(0.001)\end{array}$ & $\begin{array}{l}0.12 \\
7 \\
(0.0 \\
87)\end{array}$ & $\begin{array}{l}0.026 \\
(0.187)\end{array}$ \\
\hline $\begin{array}{l}\text { Corruption } \\
\text { index: }\end{array}$ & & & & & & & & & \\
\hline World Bank & $\begin{array}{l}0.012^{* * *} \\
(0.003)\end{array}$ & & & $\begin{array}{l}0.006 \\
(0.009)\end{array}$ & & & & & \\
\hline $\begin{array}{l}\text { Transparency } \\
\text { International } \\
\text { (TI) }\end{array}$ & & $\begin{array}{l}0.014^{* *} \\
(0.005)\end{array}$ & & & $\begin{array}{c}0.017 \\
(0.014)\end{array}$ & & & & \\
\hline
\end{tabular}


Impact of Corruption on Economic Growth: Evidence from Asian ..

\begin{tabular}{|c|c|c|c|c|c|c|c|c|c|}
\hline $\begin{array}{l}\text { International } \\
\text { Country Risk } \\
\text { Guide (ICRG) }\end{array}$ & & & $\begin{array}{c}0.002 \\
(0.003)\end{array}$ & & & $\begin{array}{r}0.009 \\
(0.081)\end{array}$ & & & \\
\hline $\begin{array}{l}\text { Control } \\
\text { variables }\end{array}$ & Yes & Yes & Yes & Yes & Yes & Yes & Yes & Yes & Yes \\
\hline Time dummies & Yes & Yes & Yes & Yes & Yes & Yes & Yes & Yes & Yes \\
\hline $\begin{array}{l}\text { BP Lagrange } \\
\text { Multiplier } \\
\text { (LM) test }\end{array}$ & $\begin{array}{c}5846.06^{*} \\
(0.00)\end{array}$ & $\begin{array}{c}5898.2 \\
9^{* * *} \\
(0.00)\end{array}$ & $\begin{array}{l}4687 \\
18^{* * *} \\
(0.00)\end{array}$ & $\begin{array}{c}2772.5 \\
3^{* * * *} \\
(0.00)\end{array}$ & $\begin{array}{r}2718 . \\
42^{* * *} \\
(0.00)\end{array}$ & $\begin{array}{c}2178.7 \\
4^{* * * *} \\
(0.00)\end{array}$ & $\begin{array}{c}5887 . \\
58^{* * * *} \\
(0.00)\end{array}$ & $\begin{array}{c}5683 . \\
96^{* *} \\
* \\
(0.00)\end{array}$ & $\begin{array}{c}2099.62^{* * *} \\
(0.00)\end{array}$ \\
\hline $\begin{array}{l}\text { Number of } \\
\text { observations }\end{array}$ & 924 & 924 & 704 & 924 & 924 & 704 & 924 & 924 & 704 \\
\hline
\end{tabular}

Notes: Standard errors are reported in parentheses. The asterisk shows the significance level of $p$-values $\left({ }^{* *} \mathrm{p}<0.05 ;{ }^{* * *} \mathrm{p}<0.01\right)$. We present the results of the Breusch-Pagan (BP) Lagrangian multiplier, $\chi^{2}$ which indicates the null hypothesis that the error variance in the regression is equal to zero.

\section{Table-4}

\section{Estimated elasticities across countries}

\begin{tabular}{|c|c|c|c|c|c|c|}
\hline & \multicolumn{2}{|c|}{$\begin{array}{l}\text { Military spending in } \\
\text { GDP (mil) }\end{array}$} & \multicolumn{2}{|c|}{$\begin{array}{l}\text { Government } \\
\text { investment in GDP } \\
\text { (inv) }\end{array}$} & \multirow{2}{*}{$\begin{array}{l}\text { World } \\
\text { corruption } \\
\left(C C I_{\text {corr }}\right)\end{array}$} & \multirow{2}{*}{$\begin{array}{r}\text { Bank } \\
\text { index } \\
\text { Net } \\
\text { elasticity }\end{array}$} \\
\hline & $\begin{array}{l}\text { Gross } \\
\text { elasticity }\end{array}$ & $\begin{array}{l}\text { Net } \\
\text { elasticity }\end{array}$ & $\begin{array}{l}\text { Gross } \\
\text { elasticity }\end{array}$ & $\begin{array}{l}\text { Net } \\
\text { elasticity }\end{array}$ & & \\
\hline Afghanistan & -0.177 & -0.109 & 1.077 & 0.802 & -0.250 & -0.414 \\
\hline Armenia & -0.372 & -0.289 & 1.069 & 0.872 & -0.377 & -0.603 \\
\hline Azerbaijan & -0.341 & -0.173 & 0.978 & 0.789 & -0.126 & -0.283 \\
\hline Bangladesh & -0.137 & -0.069 & 0.487 & 0.324 & -0.181 & -0.321 \\
\hline Bahrain & -0.437 & -0.342 & 0.855 & 0.632 & -0.286 & -0.432 \\
\hline $\begin{array}{l}\text { Brunei } \\
\text { Darussalam }\end{array}$ & -0.389 & -0.290 & 0.636 & 0.502 & -0.859 & -0.972 \\
\hline Cambodia & -0.185 & -0.072 & 0.906 & 0.745 & -0.443 & -0.432 \\
\hline China & -0.203 & -0.099 & 0.777 & 0.528 & -0.519 & -0.726 \\
\hline
\end{tabular}


Dr. Muhammad Zubair Mumtaz \& Dr. Zachary A. Smith

\begin{tabular}{|c|c|c|c|c|c|c|}
\hline Cyprus & -0.249 & -0.128 & 1.430 & 1.137 & -1.018 & -1.213 \\
\hline Georgia & -0.310 & -0.211 & 1.217 & 1.093 & -0.545 & 0.628 \\
\hline India & -0.282 & -0.143 & 1.060 & 0.875 & -0.523 & 0.726 \\
\hline Indonesia & -0.087 & -0.043 & 0.609 & 0.509 & -0.307 & -0.563 \\
\hline Iran & -0.250 & -0.183 & 1.194 & 0.870 & -0.409 & -0.643 \\
\hline Iraq & -0.295 & -0.209 & 0.490 & 0.322 & -0.153 & -0.292 \\
\hline Israel & -0.183 & -0.096 & 1.549 & 0.981 & -0.909 & -1.213 \\
\hline Japan & -0.100 & -0.041 & 1.363 & 1.086 & -1.001 & -1.323 \\
\hline Jordon & -0.575 & -0.401 & 1.080 & 0.832 & -0.754 & -0.891 \\
\hline Kazakhstan & -0.109 & -0.042 & 0.676 & 0.465 & -0.195 & -0.325 \\
\hline Kuwait & -0.585 & -0.385 & 1.469 & 1.257 & -0.808 & -1.048 \\
\hline Kyrgyzstan & -0.324 & -0.191 & 0.893 & 0.664 & -0.160 & -0.289 \\
\hline Laos & -0.102 & -0.072 & 0.631 & 0.437 & -0.194 & -0.329 \\
\hline Lebanon & -0.480 & -0.219 & 1.246 & 0.826 & -0.318 & -0.502 \\
\hline Malaysia & -0.195 & -0.089 & 1.069 & 0.874 & -0.781 & -0.832 \\
\hline Mongolia & -0.134 & -0.092 & 0.942 & 0.754 & -0.510 & 0.762 \\
\hline Myanmar & -0.281 & -0.169 & 0.466 & 0.354 & -0.089 & -0.293 \\
\hline Nepal & -0.150 & -0.101 & 0.993 & 0.683 & -0.351 & -0.543 \\
\hline Oman & -0.613 & -0.432 & 0.695 & 0.496 & -0.860 & -1.038 \\
\hline Pakistan & -0.405 & -0.352 & 0.848 & 0.655 & -0.261 & -0.438 \\
\hline Philippines & -0.150 & -0.065 & 0.685 & 0.495 & -0.432 & -0.649 \\
\hline Qatar & -0.245 & -0.119 & 0.755 & 0.500 & -0.931 & -1.094 \\
\hline Saudi Arabia & -0.597 & -0.389 & 1.312 & 1.095 & -0.681 & -0.837 \\
\hline Singapore & -0.423 & -0.376 & 0.800 & 0.605 & -1.202 & -1.493 \\
\hline
\end{tabular}


Impact of Corruption on Economic Growth: Evidence from Asian ..

\begin{tabular}{|c|c|c|c|c|c|c|}
\hline South Korea & -0.269 & -0.151 & 1.091 & 0.734 & -0.850 & -1.182 \\
\hline Sri Lanka & -0.347 & -0.230 & 0.761 & 0.545 & -0.603 & -0.840 \\
\hline Tajikistan & -0.118 & -0.056 & 0.941 & 1.023 & -0.106 & -0.392 \\
\hline Thailand & -0.162 & -0.067 & 0.827 & 0.865 & -0.570 & -0.730 \\
\hline Timor-Leste & -0.075 & -0.032 & 0.389 & 0.290 & -0.418 & -0.648 \\
\hline Turkey & -0.291 & -0.149 & 0.865 & 0.654 & -0.657 & -0.836 \\
\hline Turkmenistan & -0.317 & -0.182 & 0.891 & 0.690 & -0.072 & -0.283 \\
\hline $\begin{array}{l}\text { United Arab } \\
\text { Emirates }\end{array}$ & -0.579 & -0.421 & 0.533 & 0.437 & -0.933 & -1.039 \\
\hline Uzbekistan & -0.112 & -0.085 & 0.931 & 0.786 & -0.131 & -0.204 \\
\hline Vietnam & -0.229 & -0.153 & 0.862 & 0.664 & -0.419 & -0.659 \\
\hline
\end{tabular}

\section{Effect of various elasticities}

Table 5 demonstrates the empirical results using the elasticity measures. The results show that the gross effect negatively impacts military spending on growth. This evidence illustrates that a $10 \%$ decline in military expenditure inflates the per capita growth by $1.1 \%$. However, the findings of corruption suggest that a $10 \%$ decline in corrupt activities increases the per capita growth by $3.1 \%$. These findings corroborate findings obtained in earlier studies. In addition, we report that a $10 \%$ rise in government investment increases per capita growth by $2.2 \%$. The model also estimates the indirect effects which increase military spending. This happens in the presence of security issues that require Asian economies to spend too much to protect their sovereignty. Besides, we find an inverse relationship between investment and indirect effects on growth which indicates that a $10 \%$ decline in government investment increases the per capita growth by just $0.01 \%$. However, we find no evidence where corruption influences economic growth. Lastly, we 
estimate the parameters of net elasticity. The coefficient of military spending is -0.102 , which indicates that a decline in the net effect of military spending on growth results from a positive association with government investment. This process reduces the indirect effect of corruption, which might understate the negative consequence of military spending on growth. The estimate of net elasticity of government investment is positive; furthermore, a $10 \%$ increase in the level of government investment inflates GDP/capita growth by $2 \%$.

Table-5

Elasticity measures

\begin{tabular}{|c|c|c|c|}
\hline & Gross elasticity & Indirect & Net elasticity \\
\hline $\begin{array}{l}\text { Military } \\
\text { spending/ } \\
\text { GDP } \\
\end{array}$ & $\begin{array}{l}-0.106^{* * *} \\
(0.034)\end{array}$ & $\begin{array}{c}0.003^{* * *} \\
(0.001)\end{array}$ & $\begin{array}{l}-0.102^{* * *} \\
(0.030)\end{array}$ \\
\hline $\begin{array}{l}\text { Government } \\
\text { investment/ } \\
\text { GDP }\end{array}$ & $\begin{array}{l}0.215^{* * *} \\
(0.072)\end{array}$ & $\begin{array}{r}-0.001^{* * *} \\
(0.000)\end{array}$ & $\begin{array}{l}0.203^{* * *} \\
(0.068)\end{array}$ \\
\hline $\begin{array}{l}\text { World } \\
\text { Bank } \\
\text { corruption } \\
\text { index }\end{array}$ & $\begin{array}{l}-0.314^{* * *} \\
(0.110)\end{array}$ & $\begin{array}{r}-0.015 \\
(0.063)\end{array}$ & $\begin{array}{l}-0.460^{* * *} \\
(0.161)\end{array}$ \\
\hline
\end{tabular}

This table reports the various elasticity measures in terms of military spending/GDP, government investment/GDP, and World Bank corruption index.

Testing the robustness using alternative measures of corruption Our analyses have substantiated the general evidence that spending of government investment spurs economic activities; however, military spending and corruption decreases it. Moreover, we identified that corrupt practices lead to negative influences on military expenditure and a positive impact on government investment. Our estimates are crosssectional and it is imperative to consider the generalisation and validation of the findings. We analyse the heterogeneity issues in terms of the estimates of the variable of interest and whether they are sensitive to posit variation in explanatory variables. This study uses other measures of corruption indices of $I C R G_{\text {corr }}$ which is a combination of both $C C I_{\text {corr }}$ 
Impact of Corruption on Economic Growth: Evidence from Asian ..

and index $T I_{\text {corr }}$ to examine the robustness of the results. Table 6 confirms the association between corruption and the growth rate (Table 5).

Table-6

Elasticity measures, alternative corruption measures

\begin{tabular}{|c|c|c|c|c|c|c|}
\hline & \multicolumn{2}{|c|}{ Gross elasticity } & \multicolumn{2}{|c|}{ Indirect elasticity } & \multicolumn{2}{|c|}{ Net elasticity } \\
\hline & $\mathrm{TI}_{\text {corr }}$ & $\mathrm{ICRG}_{\mathrm{corr}}$ & $\mathrm{TI}_{\text {corr }}$ & $\mathrm{ICRG}_{\mathrm{corr}}$ & $\mathrm{TI}_{\text {corr }}$ & $\mathrm{ICRG}_{\text {corr }}$ \\
\hline $\begin{array}{l}\text { Military } \\
\text { spending } \\
\text { in GDP }\end{array}$ & $\begin{array}{c}0.105^{\text {- }} \\
(0.038)\end{array}$ & $\begin{array}{r}-0.106^{* * *} \\
(0.031)\end{array}$ & $\begin{array}{c}0.003^{* * *} \\
(0.001)\end{array}$ & $\begin{array}{c}0.003^{* * *} \\
(0.000)\end{array}$ & $\begin{array}{l}-0.102^{* * *} \\
(0.029)\end{array}$ & $\begin{array}{l}-0.101^{* * *} \\
(0.025)\end{array}$ \\
\hline $\begin{array}{l}\text { Government } \\
\text { investment } \\
\text { in GDP }\end{array}$ & $\begin{array}{c}0.231^{* * *} \\
(0.070)\end{array}$ & $\begin{array}{c}0.230^{* * *} \\
(0.078)\end{array}$ & $\begin{array}{r}-0.000^{\text {**** }} \\
(0.000)\end{array}$ & $\begin{array}{r}-0.001^{* * *} \\
(0.000)\end{array}$ & $\begin{array}{c}0.236^{\text {**** }} \\
(0.073)\end{array}$ & $\begin{array}{l}0.239^{* * * *} \\
(0.070)\end{array}$ \\
\hline $\begin{array}{l}\text { Corruption } \\
\text { index }\end{array}$ & $\begin{array}{r}-0.451^{* * * *} \\
(0.154)\end{array}$ & $\begin{array}{r}-0.009 \\
(0.007)\end{array}$ & $\begin{array}{r}-0.062 \\
(0.056)\end{array}$ & $\begin{array}{r}-0.002^{* * * *} \\
(0.001)\end{array}$ & $\begin{array}{l}-0.611^{* * *} \\
(0.138)\end{array}$ & $\begin{array}{c}-0.005 \\
(0.004)\end{array}$ \\
\hline
\end{tabular}

Comparing the results: African versus Asian economies

This section compares the results of this study with an earlier study ${ }^{54}$ to determine whether corruption causes economic growth. Table 7 provides a comparison of the finding between African and Asian economies. Employing Country-fixed effect (OLS) and System GMM, Table 8 presents the results of African and Asian economies. In African economies, the results indicate that an increase in private investment $\left(\operatorname{priv}_{i n v_{t-1}}\right)$ leads to a rise in the per-capita GDP growth rate. However, this variable has an insignificant effect on Asian countries. Military spending/GDP has an inverse relationship with economic growth in both economies. However, an increase of $1 \%$ in military spending/GDP reduces the economic growth by $0.22 \%$ and $0.49 \%$ in African and Asian

\footnotetext{
54 d'Agostino, Giorgio John Dunne and Luca Pieroni, "Corruption and growth in Africa," European Journal of Political Economy 43 (2016), 71-88, doi:

10.1016/j.ejpoleco.2016.03.002.
} 
Dr. Muhammad Zubair Mumtaz \& Dr. Zachary A. Smith

economies, respectively. This illustrates that governments in Asian countries are spending more on their military, which ultimately affects per capita GDP growth. Another essential component is government consumption/GDP which inversely influences per capita growth in both economies. It is pertinent to note that the participation of government consumption in GDP is higher for Asian countries.

Table-7

Comparing the results: African versus Asian economies

\begin{tabular}{|c|c|c|c|c|}
\hline & \multicolumn{3}{|c|}{$\begin{array}{c}\text { d'Agostino et al. (2016a) } \\
\text { (African economies) } \\
1996-2010\end{array}$} & \multirow{2}{*}{$\begin{array}{l}\text { Current } \\
\text { Study } \\
\text { (Asian } \\
\text { economies) } \\
\text { 1996-2018 } \\
\text { System GMM }\end{array}$} \\
\hline & $\begin{array}{l}\text { Country-fixed } \\
\text { effect (OLS) }\end{array}$ & System GMM & $\begin{array}{l}\text { Country-fixed } \\
\text { effect (OLS) }\end{array}$ & \\
\hline $\begin{array}{l}\text { GDP per capita } \\
\text { growth rate }_{t-1}\end{array}$ & $\begin{array}{l}0.049 \\
(0.090)\end{array}$ & $\begin{array}{l}0.224^{* *} \\
(0.098)\end{array}$ & $\begin{array}{c}0.396^{* * *} \\
(0.031)\end{array}$ & $\begin{array}{l}0.086^{*} \\
(0.050)\end{array}$ \\
\hline Private investment $t_{t-1}$ & $\begin{array}{l}0.143^{*} \\
(0.070)\end{array}$ & $\begin{array}{l}0.160^{* *} \\
(0.067)\end{array}$ & $\begin{array}{c}0.026 \\
(0.018)\end{array}$ & $\begin{array}{c}0.167 \\
(0.109)\end{array}$ \\
\hline $\begin{array}{l}\text { Military spending } \\
\text { in GDP }\end{array}$ & $\begin{array}{l}-0.290^{* * *} \\
(0.078)\end{array}$ & $\begin{array}{l}-0.218^{* * *} \\
(0.058)\end{array}$ & $\begin{array}{l}-0.173^{* * *} \\
(0.058)\end{array}$ & $\begin{array}{l}-0.489^{*} \\
(0.262)\end{array}$ \\
\hline $\begin{array}{l}\text { Government } \\
\text { investment in GDP }\end{array}$ & $\begin{array}{l}0.177^{* *} \\
(0.085)\end{array}$ & $\begin{array}{l}0.164^{* * *} \\
(0.050)\end{array}$ & $\begin{array}{c}0.006 \\
(0.035)\end{array}$ & $\begin{array}{l}0.156^{*} \\
(0.090)\end{array}$ \\
\hline $\begin{array}{l}\text { Current government } \\
\text { consumption in GDP }\end{array}$ & $\begin{array}{l}-0.111^{*} \\
(0.066)\end{array}$ & $\begin{array}{l}-0.072^{* *} \\
(0.033)\end{array}$ & $\begin{array}{l}-0.075^{* * *} \\
(0.026)\end{array}$ & $\begin{array}{l}-0.277^{* * *} \\
(0.079)\end{array}$ \\
\hline $\begin{array}{l}\text { World Bank } \\
\text { corruption index }\end{array}$ & $\begin{array}{l}-0.041^{* *} \\
(0.016)\end{array}$ & $\begin{array}{l}-0.017^{* *} \\
(0.008)\end{array}$ & $\begin{array}{l}-0.018^{* * *} \\
(0.005)\end{array}$ & $\begin{array}{l}0.192^{* *} \\
(0.083)\end{array}$ \\
\hline Regimes & $\begin{array}{l}-2.848^{*} \\
(1.511)\end{array}$ & $\begin{array}{l}-2.934^{* *} \\
(1.225)\end{array}$ & $\begin{array}{c}0.243 \\
(0.267)\end{array}$ & $\begin{array}{l}2.115^{*} \\
(1.287)\end{array}$ \\
\hline Resources & $\begin{array}{l}0.666^{* *} \\
(0.303)\end{array}$ & $\begin{array}{l}0.703^{* *} \\
(0.280)\end{array}$ & $\begin{array}{l}-0.085 \\
(0.237)\end{array}$ & $\begin{array}{l}-0.023 \\
(0.513)\end{array}$ \\
\hline Time dummies & Yes & Yes & Yes & Yes \\
\hline
\end{tabular}


Impact of Corruption on Economic Growth: Evidence from Asian ..

\begin{tabular}{|l|c|c|c|}
\hline $\begin{array}{l}\text { Second order serial } \\
\text { correlation test }\end{array}$ & -0.757 & -0.324 \\
\hline $\begin{array}{l}\text { Hansen test statistics } \\
\text { Number of }\end{array}$ & 512 & 28.478 & 35.46 \\
\hline $\begin{array}{l}\text { Nuservations } \\
\text { obser }\end{array}$ & 512 & 924 & 924 \\
\hline
\end{tabular}

Notes: This table compares the results of the current study with d'Agostino et al. (2016a) to examine the different factors that cause economic growth for Asian and African economies. The dependent variable is the growth rate of GDP. The asterisk shows the significance level of $p$-values $\left({ }^{*} \mathrm{p}<0.1 ;{ }^{* *} \mathrm{p}<0.05 ;{ }^{* * *} \mathrm{p}<0.01\right)$.

Corruption is a variable of interest in both the studies and the core objective is to determine whether corruption hurts economic growth or not. While comparing the results, we consider the World Bank corruption index as a proxy for corruption and the results report that a higher corruption level deters economic activities in both economies. Using other corruption measures (e.g., Transparency international and ICRG), the results report that higher corruption in an economy leads to lower per capita growth. The impact of two dummy variables (autocratic versus non-autocratic regimes and high versus low level of natural resources) also impact economic growth and lead to a difference in the results when comparing the two studies. Researchers ${ }^{55}$ reported that countries with democratic regimes had higher levels of growth in African countries. Alternatively, we find the opposite result for Asian economies, which indicates that the chances of economic prosperity are higher during the autocratic regime. This seems true in the sense that in some of the Asian economies, the autocratic regime exists for a long time and contributed to the betterment of the economy. Moreover, the evidence confirms that a high level of natural resources positively influences the per capita GDP

\footnotetext{
55 d'Agostino, Giorgio John Dunne and Luca Pieroni, "Corruption and growth in Africa," European Journal of Political Economy 43 (2016), 71-88, doi: 
growth for African economies. For Asian countries, we find an insignificant effect between natural resources and growth. In summary, we observe that the impact of corruption on economic activities for Asian countries is higher than African economies. In addition, the share of military spending and government consumption in GDP reduces economic growth.

\section{Conclusion}

Many researchers and academicians analysed the effect of corruption on economic performance and reported that the distortion in economic growth is due to a higher level of corruption. This study examines the activities that influence growth, specifically, the effect of government expenditures on economic growth using the sample of 42 Asian countries during the 1996 to 2018 period. We follow the endogenous growth model by including different forms of government spending and find that investment spending doesn't influence economic performance. In contrast, military expenses, spending, and corruption negatively affect economic growth. We also identify that corruption compliments military expenditures, which creates a negative influence and increases military spending. In short, countries with a high level of corruption and military spending don't yield benefits of economic growth. We also find that countries that have an autocratic regime have greater levels of economic growth. Moreover, we find an insignificant effect between the high level of natural resources and economic development. We also compare the findings of this study with an earlier study ${ }^{56}$ to determine the differences in results when comparing Asian and African economies. The findings show that the corruption level in Asian economies is higher than the level of corruption in African economies. However, military spending, government investment and consumption are the robust predictors of growth for African economies. While examining the relationship between corruption and economic performance, it is necessary to consider direct, indirect and complementary effects, which can be used to determine by interacting corruption and different modes of government expenses. Ignoring these effects, it is difficult to understand the mechanism where corruption can influence economic performance. The policy implication

\footnotetext{
${ }^{56}$ d'Agostino, Giorgio John Dunne and Luca Pieroni, "Corruption and growth in Africa," European Journal of Political Economy 43 (2016), 71-88, doi: 10.1016/j.ejpoleco.2016.03.002.
} 
Impact of Corruption on Economic Growth: Evidence from Asian ..

of this study suggests that governments of the Asian region are required to take the necessary measures to combat corruption through close monitoring of allocation of government expenditures. Further, a mechanism should be devised to monitor the government spending that may be channelised and routed through different constituencies to minimise corrupt practices and improve growth prospects in Asia. For future research, we propose that researchers provide a deeper analysis of the factors that cause corruption by specifically distinguishing between the primary causes of corruption in developed and developing markets.

Furthermore, a deeper study is required to interlink security and compulsion of military spending in order to avoid disruption in a democratic process, particularly in the developing countries. Survival of the fittest in an economically, politically and strategically defined race is yet another perspective social scientists need to dissect for the progression of peace efforts. 